\title{
Characterization of aromatic compounds and antimicrobial properties of four spice essential oils from family Lamiaceae
}

\section{Hafize Fidan ${ }^{1}$, Stanko Stankov ${ }^{1}$, Tanya Ivanova ${ }^{1}$, Albena Stoyanova ${ }^{1}$, Stanka Damyanova², Sezai Ercisli ${ }^{3}$}

\author{
1 - University of Food Technologies, Plovdiv, Bulgaria \\ 2 - Angel Kanchev University of Russe, Razgrad Branch, Bulgaria \\ 3 - Ataturk University, Erzurum, Turkey
}

\section{Keywords:}

Essential oil

Garden thyme

Rosemary

Spearmint

Sweet basil

Antibacterial

Article history:

Received 12.10.2018

Received in revised form 24.02.2019

Accepted 31.05.2019

Corresponding author:

Hafize Fidan

E-mail:

hafizefidan@abv.bg

DOI: $10.24263 / 2304-$

974X-2019-8-2-3

\section{Abstract}

Introduction. Representatives of the Lamiaceae family are widely used in the food industry as they are characterized by a high content of aromatic compounds.

Materials and methods. It was evaluated the chemical composition and antibacterial activity of essential oils of garden thyme (Thymus vulgaris L.), rosemary (Rosmarinus officinalis L.), spearmint (Mentha spicata L.), and sweet basil (Ocimum basilicum L.).

Results and discussion. The percentage ratio of volatile components obtained by GC-MS analysis of essential oil from garden thyme contains: thymol (37.90\%) and $\gamma$-terpinene $(19.44 \%)$. It has been determined eucalyptol (19.89\%) and camphor (16.86\%) in the essential oil of rosemary and carvone $(50.23 \%)$ and limonene $(13.90 \%)$ in spearmint oil, respectively. The differences in the quantitative and qualitative composition of essential oils and their aromatic components in relation to the previous researches may be probably due to different environmental and genetic factors, different chemotypes and the nutritional status of the plants as well as other factors that can influence the oil composition. Escherichia coli was the most susceptible bacterium strain. The essential oils of spearmint and rosemary possessed the most pronounced antibacterial activities against Escherichia coli (with inhibition zone: $32.00 \mathrm{~mm}$ and $30.00 \mathrm{~mm}$ ).

Conclusions. The results obtained provide a basis for a thorough examination of the chemical composition and antimicrobial properties of various representatives of Lamiaceae family with a view to a wide usage in food technology. 


\section{Introduction}

The family of Lamiaceae (also known as Labiatae) has very large distribution, containing about 236 genera and 6900 to 7200 species. Representatives of the Lamiaceae family are widely used for various purposes, but their most extensive usage is in the food industry as they are characterized by a high content of aromatic compounds. Sweeet basil, spearmint, rosemary, sage, oregano and garden thyme are only some of the species with wide usage in culinary production all over the world [22].

Garden thyme (Thymus vulgaris L.) is an evergreen herb, native to the southern Europe and the Mediterranean [20]. The plant has been used since ancient times as a culinary ingredient, to add flavor to cheeses $[4,2]$ and liqueurs $[29,26]$ and to flavor meats such as rabbit, boar, and lamb [12].

The herb garden thyme is pungent in taste and contains protein, crude fiber, minerals, vitamins, etc. [3]. The essential oil of garden thyme and the compound thymol have antimicrobial activity in vitro against Escherichia coli strains [7, 13]. Garden thyme essential oil is one of the most commonly used aromatic products in the home kitchens as well as in the food industry as preservatives and antioxidants.

A study including 21 essential oils and five pathogenic bacteria, demonstrated that the garden thyme had one of the most potent bacteriostatic and bactericidal effects against Escherichia coli, Salmonella enteritidis, Listeria monocytogenes, and Staphylococcus aureus [36].

Rosemary (Rosmarinus officinalis L.) is one of the most economically important plants of the family Lamiaceae. The name "rosemary" derives from the Latin words "ros", meaning "dew" and "marinus," meaning "sea" - "dew of the sea". Rosemary has been used in the culinary since decades. Native to the Mediterranean region, the plant is now widely distributed all over the world mainly due to its culinary, medicinal, and commercial uses including in the fragrance and food industries [21]. Both fresh and dried leaves of rosemary have been used for their characteristic aroma in cooking or consumed in small amounts as herbal tea, while rosemary extracts are routinely employed as natural antioxidant to improve the shelf life of perishable foods. The culinary, medicinal, and fragrance uses of rosemary are attributed to the vast arrays of chemical constituents collectively known as plant secondary metabolites [40]. Moreover, one group aromatic compounds are with small molecular weight, called essential oils which play vital role in the fragrance and culinary properties of the plant [15]. The application of rosemary in the culinary practice is related to the corresponding chemotype of the spice, which has pronounced flavoring properties.

According to $\mathrm{Fu}$ et al. [18] minimum inhibitory concentrations of rosemary essential oil ranged from $0.125 \%$ to $1.000 \%(\mathrm{v} / \mathrm{v})$ and possessed significant antimicrobial effects against Gram-positive bacteria, three Gram-negative bacteria.

Spearmint (Mentha spicata L.) is an aromatic plant that can be used fresh or as dried leaves or powder, as a seasoning and flavoring herb, or traditionally as herbal tea [25]. In addition, spearmint essential oil has economic relevance due to its use in perfumery, confectionary, cosmetics and pharmaceutical preparations. The fresh and dried spearmint leaves have been used as a flavoring agent in various food products, including cheese and dough (Iranian yoghurt drink), chocolate, beverages, jellies, syrups, candies, ice creams, and chewing gum [32].

Spearmint essential oil had strong activity against S. aureus, E. coli, Candida albicans and C. tropicalis [35]. Besides its flavoring properties, spearmint is also widely used as an antimicrobial agent and as a preservative in food, mainly because of its oxygenated compounds $[27,11]$. 
Sweet basil (Ocimum basilicum L.), is a culinary herb of major importance. Most culinary and ornamental basils are cultivars of the species $O$. basilicum, but other species are also grown and there are many hybrids between species [38]. Sweet basil can be dried or used fresh, similar to many other pot-herbs. It is best used fresh, as dried it will lose its flavor. Sweet basil leaves containing essential oil of distinctive aroma can be used both fresh and dried to spice up various kinds of meals. Apart of culinary use, sweet basil has been traditionally applied as a medicinal herb [33]. The presence of essential oil and its composition determine the specific aroma of plants and the flavor of the condiment [33]. Although essential oils in different basil cultivars are variable, prevalent components are monotherpenes and phenylpropanoids [28]. Fresh sweet basil leaves is used as an ingredient in various dishes and food preparations, especially in the Mediterranean cuisine. Due to its antimicrobial $[9,37]$ and insecticidal [8] activities and very pleasant aroma, sweet basil essential oil is widely used in the food.

Its usage in culinary practice is based on the possibility of fresh and dried leaves to emphasize meat and vegetable flavors, giving them a pronounced aromatic flavor. Most often aromatic components in fresh spices are obtained by low temperature extraction with vegetable oils used in culinary practice. The resulting aromatic oil substances are successfully used, such as salad dressings, spices for meat and vegetable soups, poultry and game dishes.

Due to the wide use of the Lamiacea spices in the food technology and the scarce information in Bulgaria about their aromatic composition and antimicrobial properties against foodborne pathogens, it have been involved the need for their further examination.

The aim of the present study is to characterize the aromatic components in the essential oils of four spices of the family Lamiaceae and antimicrobial properties against pathogenic bacteria, causing foodborne illnesses, with potential possibilities for their application in food technology.

\section{Materials and methods}

\section{Plant Material}

Garden thyme (Thymus vulgaris L.), rosemary (Rosmarinus officinalis L.), spearmint (Mentha spicata L.), sweet basil (Ocimum basilicum L.) were purchased from the merchant local market in Plovdiv. Samples were identified by an expert in Agricultural University of Plovdiv, Bulgaria.

The moisture content of raw materials was determined by drying to constant weight at $105^{\circ} \mathrm{C}[34]$.

\section{Essential oils}

The essential oils were obtained with modification of hydrodistillation for $150 \mathrm{~min}$ in the laboratory glass apparatus according to the British Pharmacopoeia [6].

The oils were dried over anhydrous sulfate and stored in tightly closed dark vials at $4{ }^{\circ} \mathrm{C}$ until analysis.

The GC-MS analysis was carried out with an Agilent 5975C MSD system coupled to an Agilent 7890A gas chromatograph (Agilent Technologies Inc., Santa Clara, CA). Agilent $\mathrm{J} \& \mathrm{~W}$ HP-5MS column $(0.25 \mu \mathrm{m}, 30 \mathrm{~m} \times 0.25 \mathrm{~mm})$ was used with helium as a carrier gas $\left(1.0 \mathrm{~mL} \mathrm{~min}^{-1}\right)$. The operational conditions were: oven temperature $35^{\circ} \mathrm{C} / 3 \mathrm{~min}, 5^{\circ} \mathrm{C} / \mathrm{min}$ to $250^{\circ} \mathrm{C}$ for $3 \mathrm{~min}$, total run time $49 \mathrm{~min}$; injector temperature $260^{\circ} \mathrm{C}$; ionization voltage 70 $\mathrm{eV}$; ion source temperature $230^{\circ} \mathrm{C}$; transfer line temperature $280^{\circ} \mathrm{C}$; solvent delay $4.25 \mathrm{~min}$ 
and mass range $50-550 \mathrm{Da}$. The MS was operated in scan mode. One $\mu \mathrm{L}$ of the sample was injected into the GC/MS system at split ratio 30:1. The GC analysis was carried out using an Agilent 7890A GC system; FID temperature $270{ }^{\circ} \mathrm{C}$. In order to obtain the same elution order with $\mathrm{GC} / \mathrm{MS}$, simultaneous triplicate injections were done by using the same column and the same operational conditions.

The identification of compounds was made by comparing their mass spectra with those from mass spectra libraries [1] and by comparing the literature and estimated Kovat's (retention) indices that were determined using mixtures of homologous series of normal alkanes from $\mathrm{C}_{8}$ to $\mathrm{C}_{40}$ in hexane, under the conditions described above. The percentage ratio of volatile components was computed using the normalization method of the GC/FID peak areas.

\section{Determination of antibacterial activity}

As test microorganisms were used strains of pathogenic bacteria, reported as causing foodborne infections, intoxications and toxicoinfections. Antibacterial activity of essential oils was tested against Gram-positive bacteria - Listeria monocytogenes NCTC 11994 and Staphylococcus aureus ATCC 25093, and Gram-negative bacteria - Escherichia coli ATCC 8739 and Salmonella enterica subsp. enterica serovar Abony NCTC 6017. The selective growth media were: Listeria Oxford Agar Base/Merck/; Baird Parker Agar Base with Egg Yolk Tellurite emulsion supplement /Merck/, Rapid' E.coli 2 Agar /BioRad/ and Mac CONKEY Agar /Merck/, respectively.

The media were inoculated with 24-hour suspension of the bacterial species.

Melted and cooled to $45{ }^{\circ} \mathrm{C}$ selective media were inoculated with the tested microorganisms and next equally dispensed into Petry dishes. After setting of the media, sterile rings $(\varnothing 6 \mathrm{~mm})$ were placed on, and the amount of each sample $(0.05 \mathrm{~mL})$ was put into the rings. Petry dishes were incubated at $37^{\circ} \mathrm{C}$ for 24 or $48 \mathrm{~h}$ according to the bacterial spices, and then the distinct zone of growth inhibition $(\mathrm{mm})$ around the rings was measured. The used inoculums have resulted as an actual concentration cells of $L$. monocytogenes, $S$. aureus, E. coli, S. enterica into the responding selective medium about $3 \times 10^{5} \mathrm{CFU} / \mathrm{mL}$. The total plate count was estimated by the conventional plate-counting technique using appropriate dilution.

\section{Results and discussion}

\section{Chemical composition of essential oils}

Garden thyme (Thymus vulgaris L.).

The moisture of the plants was determined as $82.75 \% \pm 0.80$. The yield of essential oil was $0.56 \% \pm 0.00$ (in abs. dry mass was $3.26 \% \pm 0.03$ ). The oil was light yellow liquid with a characteristic, spicy-phenolic odor (Table 1). The oil is consisted by 35 components, representing $98.89 \%$ of the total content. Twelve of them were in concentrations over $1 \%$ and the rest 23 constituents were in concentrations under 1\%. The major constituents (up 3\%) of the oil were as follows: thymol (37.90\%), $\gamma$-terpinene (19.44\%), $p$-cymene $(8.84 \%), \delta$-2carene (3.92\%), carvacrol (3.60\%), and $\beta$-caryophyllene (3.37\%). The results indicated that Bulgarian essential oil obtained from $T$. vulgaris is from thymol chemotype [19], which may also have a profound influence on its bioactivity, flavor, and aroma profile. 
Table 1

Chemical composition of essential oil of garden thyme, rosemary, spearmint, sweet basil

\begin{tabular}{|c|c|c|c|c|c|c|}
\hline \multirow[b]{2}{*}{ № } & \multirow[b]{2}{*}{ Compounds } & \multirow[b]{2}{*}{ RI } & \multicolumn{4}{|c|}{ Content, $\%$} \\
\hline & & & $\begin{array}{c}\text { Garden } \\
\text { thyme }\end{array}$ & Rosemary & Spearmint & $\begin{array}{c}\text { Sweet } \\
\text { basil }\end{array}$ \\
\hline 1 & Tricyclene & 922 & $-*$ & $0.42 \pm 0.00$ & - & - \\
\hline 2 & $\alpha$-Pinene & 939 & $2.39 \pm 0.02$ & $13.37 \pm 0.12$ & $1.31 \pm 0.01$ & $0.56 \pm 0.00$ \\
\hline 3 & Camphene & 954 & $0.33 \pm 0.00$ & $7.22 \pm 0.07$ & $0.27 \pm 0.00$ & $0.10 \pm 0.00$ \\
\hline 4 & Sabinene & 969 & $0.26 \pm 0.00$ & $0.10 \pm 0.00$ & $0.86 \pm 0.00$ & $0.48 \pm 0.00$ \\
\hline 5 & $\beta$-Pinene & 979 & $0.37 \pm 0.00$ & $2.37 \pm 0.02$ & $1.24 \pm 0.01$ & $0.79 \pm 0.00$ \\
\hline 6 & Octen-3-ol & 982 & $2.81 \pm 0.02$ & - & - & - \\
\hline 7 & $\beta$-Myrcene & 991 & $2.22 \pm 0.02$ & $1.81 \pm 0.01$ & $1.63 \pm 0.01$ & $0.89 \pm 0.00$ \\
\hline 8 & $\alpha$-Phellandrene & 996 & - & $4.27 \pm 0.04$ & - & - \\
\hline 9 & $\delta$-2-Carene & 998 & $3.92 \pm 0.03$ & $2.13 \pm 0.02$ & - & - \\
\hline 10 & $\alpha$-Terpinene & 1018 & - & - & $0.24 \pm 0.00$ & - \\
\hline 11 & $p$-Cymene & 1025 & $8.84 \pm 0.08$ & - & - & - \\
\hline 12 & Limonene & 1030 & $0.54 \pm 0.00$ & - & $13.90 \pm 0.12$ & $0.33 \pm 0.00$ \\
\hline 13 & Eucalyptol & 1032 & $0.24 \pm 0.00$ & $19.89 \pm 0.18$ & $0.99 \pm 0.00$ & $8.26 \pm 0.08$ \\
\hline 14 & cis- $\beta$-Ocimene & 1040 & - & $0.15 \pm 0.00$ & - & $1.48 \pm 0.01$ \\
\hline 15 & 2-Phenylethanal & 1047 & - & $0.10 \pm 0.00$ & - & - \\
\hline 16 & trans- $\beta$-Ocimene & 1050 & $0.36 \pm 0.00$ & $0.13 \pm 0.00$ & $0.20 \pm 0.00$ & $0.13 \pm 0.00$ \\
\hline 17 & $\gamma$-Terpinene & 1055 & $19.44 \pm 0.18$ & $2.26 \pm 0.02$ & $0.46 \pm 0.00$ & $0.28 \pm 0.00$ \\
\hline 18 & $\alpha$-Terpinolene & 1088 & - & $1.81 \pm 0.01$ & $0.38 \pm 0.00$ & - \\
\hline 19 & $\beta$-Linalool & 1092 & $2.59 \pm 0.02$ & $0.96 \pm 0.00$ & $0.53 \pm 0.00$ & $30.52 \pm 0.29$ \\
\hline 20 & $p$-Mentha-3-one & 1131 & - & - & $0.87 \pm 0.00$ & - \\
\hline 21 & (+)-Camphor & 1126 & - & $16.86 \pm 0.16$ & - & $0.33 \pm 0.00$ \\
\hline 22 & trans-Menthone & 1136 & - & - & $1.11 \pm 0.01$ & - \\
\hline 23 & Pinocarvone & 1157 & - & $0.67 \pm 0.00$ & - & - \\
\hline 24 & Isomenthol & 1158 & - & - & $0.30 \pm 0.00$ & - \\
\hline 25 & Terpinen-4-ol & 1163 & - & - & - & $0.90 \pm 0.00$ \\
\hline 26 & (-)-Menthol & 1164 & - & - & $0.84 \pm 0.00$ & - \\
\hline 27 & Borneol & 1169 & $1.65 \pm 0.01$ & $5.27 \pm 0.05$ & - & - \\
\hline 28 & (+)-Menthol & 1168 & - & - & $1.29 \pm 0.01$ & \\
\hline 29 & Terpinene-4-ol & 1179 & $0.71 \pm 0.00$ & $2.20 \pm 0.02$ & - & - \\
\hline 30 & Methylchavicol & 1186 & - & - & - & $13.16 \pm 0.12$ \\
\hline 31 & Piperitol & 1196 & - & $0.38 \pm 0.00$ & - & - \\
\hline 32 & Dihydrocarvone & 1204 & - & - & $3.37 \pm 0.03$ & - \\
\hline 33 & cis-Carveol & 1208 & - & - & $0.34 \pm 0.00$ & - \\
\hline 34 & $\alpha$-Terpineol & 1189 & $0.37 \pm 0.00$ & $4.10 \pm 0.04$ & - & $1.07 \pm 0.01$ \\
\hline 35 & Verbenone & 1193 & - & $3.69 \pm 0.03$ & - & - \\
\hline
\end{tabular}




\begin{tabular}{|c|c|c|c|c|c|c|}
\hline & Chemical composition o & essenti & l oil of garden & hyme, rosem & $\begin{array}{r}\text { Tabl } \\
\text { ry, spearmint } \\
\end{array}$ & $\begin{array}{l}1 \text { (Continue) } \\
\text { sweet basil }\end{array}$ \\
\hline & & & & Cont & nt, $\%$ & \\
\hline № & Compounds & $\mathbf{R I}$ & $\begin{array}{c}\text { Garden } \\
\text { thyme }\end{array}$ & Rosemary & Spearmint & $\begin{array}{c}\text { Sweet } \\
\text { basil }\end{array}$ \\
\hline 36 & $\beta$-Citral & 1215 & $0.13 \pm 0.00$ & - & - & - \\
\hline 37 & Pulegone & 1216 & - & - & $0.87 \pm 0.00$ & - \\
\hline 38 & (-)-Carvone & 1218 & - & - & $50.23 \pm 0.49$ & - \\
\hline 39 & Piperitone & 1228 & - & $0.25 \pm 0.00$ & - & - \\
\hline 40 & Thymol methyl ether & 1229 & $0.98 \pm 0.00$ & - & - & - \\
\hline 41 & $p$-Menth-1-en-3-one & 1231 & - & - & $2.22 \pm 0.02$ & - \\
\hline 42 & Thymoquinone & 1260 & $0.22 \pm 0.00$ & - & - & - \\
\hline 43 & Isomenthyl acetate & 1282 & - & - & $0.79 \pm 0.00$ & - \\
\hline 44 & Thymol & 1290 & $37.90 \pm 0.36$ & - & - & - \\
\hline 45 & Bornyl acetate & 1285 & - & $3.37 \pm 0.03$ & - & $0.51 \pm 0.00$ \\
\hline 46 & Carvacrol & 1292 & $3.60 \pm 0.03$ & - & - & - \\
\hline 47 & Eugenol & 1337 & $0.51 \pm 0.05$ & $0.41 \pm 0.00$ & - & $11.74 \pm 0.09$ \\
\hline 48 & cis-Carvyl acetate & 1344 & - & - & $1.11 \pm 0.01$ & - \\
\hline 49 & trans-Carveyl acetate & 1365 & - & - & $0.25 \pm 0.00$ & - \\
\hline 50 & Methyleugenol & 1371 & $0.11 \pm 0.00$ & $0.53 \pm 0.00$ & - & - \\
\hline 51 & $\beta$-Bourbonene & 1388 & - & - & $1.21 \pm 0.01$ & - \\
\hline 52 & $\beta$-Elemene & 1391 & - & - & $0.47 \pm 0.00$ & $2.28 \pm 0.02$ \\
\hline 53 & $\beta$-Caryophyllene & 1419 & $3.37 \pm 0.03$ & $1.20 \pm 0.01$ & $2.77 \pm 0.02$ & $0.42 \pm 0.00$ \\
\hline 54 & $\alpha$-Bergamotene & 1426 & - & - & - & $6.36 \pm 0.06$ \\
\hline 55 & $\beta$-Cubebene & 1429 & $1.42 \pm 0.01$ & $0.14 \pm$ & $2.65 \pm 0.02$ & - \\
\hline 56 & $\gamma$-Elemene & 1433 & - & - & $0.83 \pm 0.00$ & - \\
\hline 57 & $\delta$-Elemene & 1435 & $0.30 \pm 0.00$ & - & - & - \\
\hline 58 & $\beta$-Elemene & 1451 & $0.29 \pm 0.00$ & - & - & - \\
\hline 59 & $\alpha$-Humulene & 1454 & - & - & $0.38 \pm 0.00$ & $0.85 \pm 0.00$ \\
\hline 60 & $\alpha$-Caryophyllene & 1454 & $0.60 \pm 0.00$ & $0.23 \pm 0.00$ & - & - \\
\hline 61 & $\gamma$-Muurolene & 1483 & - & - & - & $4.33 \pm 0.04$ \\
\hline 62 & Bicyclogermacrene & 1499 & - & - & $1.26 \pm 0.01$ & - \\
\hline 63 & $\beta$-Bisabolene & 1501 & $0.23 \pm 0.00$ & - & - & - \\
\hline 64 & $\alpha$-Bulnesene & 1507 & & & - & $2.00 \pm 0.02$ \\
\hline 65 & $\gamma$-Cadinene & 1513 & $0.33 \pm 0.00$ & - & - & $1.52 \pm 0.01$ \\
\hline 66 & $\delta$-Cadinene & 1523 & - & - & $0.64 \pm 0.00$ & - \\
\hline 67 & $\delta$-Cadinene & 1524 & $0.27 \pm 0.00$ & - & - & - \\
\hline 68 & (-)-Spathulenol & 1572 & - & - & $0.32 \pm 0.00$ & - \\
\hline 69 & Germacrene D-4-ol & 1570 & $0.51 \pm 0.00$ & - & - & - \\
\hline 70 & Ledene oxide & 1578 & - & - & $0.45 \pm 0.00$ & - \\
\hline
\end{tabular}




\begin{tabular}{|c|c|c|c|c|c|c|}
\hline \multirow[b]{3}{*}{ № } & Chemical composition of & essenti & oil of garde & hyme, rosem & $\begin{array}{r}\text { Tab } \\
\text { ry, spearmin }\end{array}$ & $\begin{array}{l}1 \text { (Continue) } \\
\text { sweet basil }\end{array}$ \\
\hline & \multirow[b]{2}{*}{ Compounds } & \multirow[b]{2}{*}{ RI } & \multicolumn{4}{|c|}{ Content, $\%$} \\
\hline & & & $\begin{array}{c}\text { Garden } \\
\text { thyme }\end{array}$ & Rosemary & Spearmint & $\begin{array}{c}\text { Sweet } \\
\text { basil }\end{array}$ \\
\hline 71 & Caryophyllene oxide & 1580 & $0.47 \pm 0.00$ & $0.74 \pm 0.00$ & $0.56 \pm 0.00$ & - \\
\hline 72 & Germacrene D & 1580 & - & $0.19 \pm 0.00$ & - & - \\
\hline 73 & Cubenol<1,10-di-epi- $>$ & 1618 & - & - & $0.29 \pm 0.00$ & - \\
\hline 74 & $\delta$-Cadinol & 1619 & - & $0.66 \pm 0.00$ & $0.61 \pm 0.00$ & $1.92 \pm 0.01$ \\
\hline 75 & $\tau$-Cadinol & 1634 & - & $0.73 \pm 0.00$ & $0.52 \pm 0.00$ & $1.07 \pm 0.01$ \\
\hline 76 & $\alpha$-Cadinol & 1641 & - & $0.40 \pm 0.00$ & $0.39 \pm 0.00$ & $6.53 \pm 0.06$ \\
\hline 77 & Phytol & 2105 & $0.29 \pm 0.00$ & - & - & - \\
\hline 78 & Squalene & 2817 & $0.32 \pm 0.00$ & - & - & - \\
\hline
\end{tabular}

The moisture of the rosemary sample was $64.00 \% \pm 0.60$. The yield of essential oil was $1.09 \% \pm 0.01$ (in abs. dry mass was $3.03 \% \pm 0.03$ ). The oil was light yellow liquid with a characteristic, refreshing, pleasant odor. The oil is composed by 34 components (Table 1) representing $99.00 \%$ of the total content. Sixteen of them were in concentrations over $1 \%$ and the rest 18 constituents were in concentrations under $1 \%$. It is obvious that the major constituents (up 3\%) of the oil were as follows: 1,8-cineole $(19.89 \%),(+)$-camphor $(16.86 \%)$, $\alpha$-pinene $(13.37 \%)$, camphene $(7.22 \%)$, borneol $(5.27 \%), \alpha$-phellandrene $(4.27 \%), \alpha$ terpineol $(4.10 \%)$, verbenone $(3.69 \%)$, and bornyl acetate $(3.37 \%)$. One of the values of aromatic components in the composition of the essential oil of rosemary is comparable to those obtained by De Mastro et al. [14]. The results indicated that Bulgarian essential oil obtained from $R$. officinalis is from camphor chemotype [19]. The differences in chemical composition were explained with the different extraction methodologies used.

The moisture of the spearmint sample was $84.60 \% \pm 0.81$. The yield of essential oil was $0.83 \% \pm 0.00$ (in abs. dry mass was $5.41 \% \pm 0.05$ ). The oil was light yellow liquid with a fresh, caraway-minty odor (Table 1). The results show that 40 components representing $98.95 \%$ of the total content were identified in the oil. Fourteen of them were in concentrations over $1 \%$ and the rest 26 constituents were in concentrations under $1 \%$. It is clear that the major constituents (up 3\%) of the oil were as follows: (-) carvone $(50.23 \%)$ and limonene $(13.90 \%)$, that qualitative and quantitative results are comparable with that identified from Nikšić et al. [31]. Through aromatic compounds isolated from M. spicata in Bulgaria, the carvone/limonene chemotype of the tested sample was established [19].

The moisture content of the sweet basil sample was $88.71 \% \pm 0.86$. The yield of essential oil was $0.19 \% \pm 0.00$ (in abs. dry mass was $1.70 \% \pm 0.01$ ). The oil was light yellow liquid with typical fresh-spicy odor. Results presented on Table 1 show that the tested oil was consisted of 27 components, representing $98.81 \%$ of the total content. Fourteen of them were in concentrations over $1 \%$ and the rest 13 constituents were in concentrations under $1 \%$. As seen the major constituents (up 3\%) of the oil were as follows: $\beta$-linalool $(30.52 \%)$, methylchavicol $(13.16 \%)$, eugenol $(11.74 \%), 1,8$-cineole $(8.26 \%), \alpha$-cadinol $(6.53 \%), \alpha$ bergamotene $(6.36 \%)$, and $\gamma$-muurolene $(4.33 \%)$, comparable to results obtained from other researchers [10]. The results indicated that Bulgarian essential oil obtained from sweet basil is a linalool chemo type [19]. 
The classification of the identified compounds, based on functional groups, is summarized in Figure 1. The predominant participation of oxidized monoterpenes in the essential oil of spearmint, rosemary and sweet basil is established.

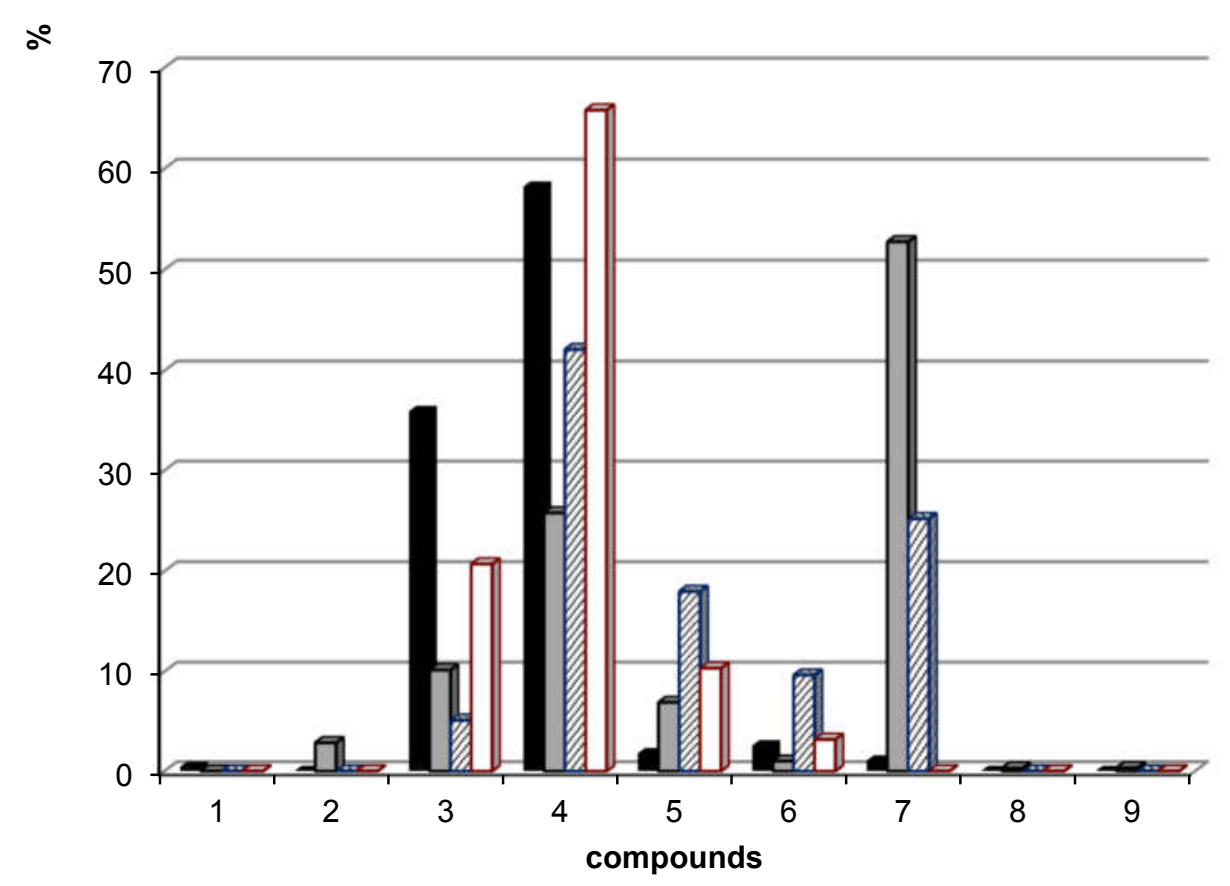

\section{- rosmary $\square$ garden thyme $\quad$ sweet basil $\square$ spearmint}

Figure 1. Group of components in essential oils from Lamiaceae, \%,

1-hydrocarbons,

2-oxygenated hydrocarbons,

3-monoterpene hydrocarbons;

4-oxygenated monoterpenes;

5-sesquiterpene hydrocarbons,

6-oxygenated sesquiterpenes,

7-phenylpropanoids;

8-diterpenes;

9-triterpenes.

Two groups of compounds were dominant in rosemary essential oil (Fig. 1), as oxygenated monoterpenes $(58.21 \%)$ and monoterpene hydrocarbons $(35.98 \%)$, followed by oxygenated sesquiterpenes $(2.56 \%)$, sesquiterpene hydrocarbons $(1.78 \%)$, and phenylpropanoids $(1.05 \%)$.

Compounds, identified in garden thyme essential oil (Fig. 1) were phenylpropanoids (52.75\%), ogygenated monoterpenes $(25.78 \%)$, monoterpene hydrocarbons $(10.14 \%)$, sesquiterpene hydrocarbons (6.89\%), oxygenated hydrocarbons $(2.84 \%)$, ogygensesquiterpenes $(0.99 \%)$, triterpenes $(0.32 \%)$, and diterpenes $(0.29 \%)$. 
Duke [16] summarized that the major aromatic components derived from the essential oil of $T$. vulgaris were as follows: thymol (23-60\%), $\gamma$-terpinene (18-50\%), p-cymene (8$44 \%$ ) carvacrol $(2-8 \%)$, and linalool $(3-4 \%)$. The reason for the different results may be caused by the origin of the sample, environmental differences, age of the plant, dissimilarities in method of isolation and seasonality.

Oxygenated monoterpenes (42.09\%), phenylpropanoids $(25.20 \%)$, and sesquiterpene hydrocarbons $(17.98 \%)$ were the dominant group in sweet basil essential oil (Fig. 1), followed by oxygenated sesquiterpenes $(9.63 \%)$, and oxygenated hydrocarbons $(5.10 \%)$.

Oxygenated monoterpenes $(65.80 \%)$ were the dominant group in spearmint essential oil, followed by monoterpene hydrocarbons $(20.71 \%)$, sesquiterpene hydrocarbons $(10.32 \%)$, and phenylpropanoids $(3.17 \%)$.

The differences in the quantitative and qualitative composition of essential oils of garden thyme, rosemary, spearmint and sweet basil and their aromatic components in relation to the previous researches may be probably due to different environmental and genetic factors, different chemotypes and the nutritional status of the plants as well as other factors that can influence the oil composition.

\section{Antibacterial activity}

The results of antibacterial testing are presented in Table 2.

All essential oils showed good antibacterial potential against tested four strains of foodborne pathogens. E.coli was the most susceptible bacterium strain. The essential oils of spearmint and rosemary possessed the most pronounced antibacterial activities against $E$. coli (with inhibition zone: $32.00 \mathrm{~mm}$ and $30.00 \mathrm{~mm}$ ). Garden thyme was most effective against E. coli due to the two major constituents as thymol and carvacrol, because of their ability to break the outer membrane of Gram-negative bacteria and increase the permeability of the cytoplasmic membrane. On the other hand, the essential oil of sweet basil showed highest antibacterial property against $S$. enterica owing to the presence of the major compound linalool.

The weakest potential was observed by the spearmint oil against $S$. enterica. All these spices, widely used in culinary technology contain compounds that have been shown to possess antibacterial functions. Studies have shown that constituents with a phenolic structure in essential oils, such as eugenol, carvacrol and thymol have the greatest antibacterial activities, followed by aldehydes, ketones, alcohols, ethers and hydrocarbons $[39,24]$.

Table 2

Diameter of zones of growth inhibition ( $\mathrm{mm})$ of tested pathogenic bacteria

\begin{tabular}{|l|c|c|c|c|}
\hline \multirow{2}{*}{ Bacteria } & $\begin{array}{c}\text { E. coli } \\
\text { ATCC } \\
\mathbf{8 7 3 9}\end{array}$ & $\begin{array}{c}\text { S. enterica } \\
\text { NCTC 6017 }\end{array}$ & $\begin{array}{c}\text { L. mono- } \\
\text { cytogenes } \\
\text { NCTC 11994 }\end{array}$ & $\begin{array}{c}\text { S. aureus } \\
\text { ATCC } \\
\mathbf{2 5 0 9 3}\end{array}$ \\
\cline { 2 - 5 } & \multicolumn{4}{|c|}{ Zones of growth inhibition (mm) } \\
\hline Garden thyme & $21.01 \pm 0.20$ & $12.02 \pm 0.11$ & $19.01 \pm 0.18$ & $20.03 \pm 0.19$ \\
\hline Rosemary & $30.04 \pm 0.28$ & $11.01 \pm 0.10$ & $13.02 \pm 0.12$ & $11.01 \pm 0.10$ \\
\hline Spearmint & $32.00 \pm 0.30$ & $12.00 \pm 0.11$ & $6.00 \pm 0.05$ & $11.02 \pm 0.10$ \\
\hline Sweet basil & $17.01 \pm 0.16$ & $20.03 \pm 0.19$ & $7.02 \pm 0.06$ & $15.02 \pm 0.14$ \\
\hline
\end{tabular}


Our results for garden thyme were in agreement with the findings of El Hattabi et al. [17].

The results of the antibacterial activity of the spearmint essential oil were lower than the findings of Horváth and Koščová [23] reported the highest antibacterial properties against $S$. aureus CCM 4223 with inhibition zone varied at a range of $35.67 \mathrm{~mm}$. The results obtained in this study are comparable to the findings of Moghaddam et al. [30, 37] reported that sweet basil essenatial oil showed inhibition zones against $S$. aureus $(29.20-30.56 \mathrm{~mm})$, and E. coli $(17.48-23.58 \mathrm{~mm})$.

Differences in the geographic environment, the cultivar type, age of the plant, different methods of isolation, and seasonality of the samples could be the reasons for the obtained differences in spectrum of antibacterial activity.

\section{Conclusion}

In the present study the aromatic composition and antibacterial properties of essential oils of thyme, rosemary, spearmint, and sweet basil were investigated. The results show the presence of alcohols and ketones in the aromatic composition of the essential oil. The identified aromatic compounds exhibit antimicrobial properties against foodborne pathogens. The essential oil of garden thyme possessed the strongest antimicrobial activity against $S$. aureus and L. monocytogenes. Otherwise, essential oil of sweet basil showed most pronounced antimicrobial properties against $S$. enterica, while $E$. coli was most susceptible to the essential oil of spearmint and rosemary. The results obtained provide a basis for a thorough examination of the chemical composition and antimicrobial properties of various representatives of Lamiaceae family with a view to a wide usage in food technology.

\section{References}

1. Adams R. (2001), Identification of Essential Oil Components by Gas Chromatography Quadrupole Mass Spectroscopy. Carol Stream, Illinois: Allured Pub. Corporation.

2. Akarca G., Çaglar A., Tomar O. (2016), The effects of spicing on quality of mozzarella cheese, Mljekarstvo, 66, pp. 112-121.

3. Alireza K, Faeghe H. Siamak S., Negar B. (2015), Study of the effect of extract of Thymus vulgaris on anxiety in male rats, $J$ Tradit Complement Med, pp. 1-5.

4. Aygun O., Aslantas O., Oner S. (2005), A survey on the microbiological quality of Carra, a traditional Turkish cheese, J Food Eng, 66, pp. 401-404.

5. Balasubramani C., Moola A.K., Vivek K., Kumari B.D.R. (2018), Formulation of nanoemulsion from leaves essential oil of Ocimum basilicum L. and its antibacterial, antioxidant and larvicidal activities (Culex quinquefasciatus), Microb. Pathog., 125, pp. 475-485.

6. Balinova-Tzvetkova A., Diakov G. (1974), On improved apparatus for microdistillation of rose flowers, Plant Sci., 11(2), pp. 79-85.

7. Boruga O., Jianu Mişcă C., Goleț I., Gruia A.T., Horhat F.G. (2014), Thymus vulgaris essential oil: chemical composition and antimicrobial activity, J Med Life, 7(3), pp. 5660 .

8. Bowers W.S., Nishida R. (1980), Potent juvenile hormones mimics from sweet basil, Science, 209, pp. 1030-1332. 
9. Bozin B., Mimica-Dukic N., Simin N., Anackov G. (2006), Characterization of the volatile composition of essential oils of some Lamiaceae spices and the antimicrobial and antioxidant activities of the entire oils, J. Agric. Food Chem, 54, pp. 1822-1828.

10. Chenni M., El Abed D., Rakotomanomana N., Fernandez X., Chemat F. (2016), Comparative study of essential oils extracted from Egyptian basil leaves (Ocimum basilicum L.) using hydro-distillation and solvent-free microwave extraction, Molecules, 21(1), pp. 113.

11. Cirlini M., Mena P., Tassotti M., Herrlinger K.A., Nieman K.M., Dall'Asta S., Del Rio D. (2016), Phenolic and volatile composition of a dry spearmint (Mentha spicata L.) extract, Molecules, 21, pp. 1-15.

12. Cornara L., La Rocca A., Marsili S., Mariotti M.G. (2000), Traditional uses of plants in the eastern Riviera (Liguria, Italy), J Ethnopharmacol, 125, pp. 16-30.

13. Dauqan E. M.A., Abdullah A. (2017), Medicinal and functional values of thyme (Thymus vulgaris L.) herb, Int J Appl Biol Pharm., 5, pp. 17-22.

14. De Mastro G., Ruta C., Mincione A., Poiana M. (2004), Bio-morphological and chemical characterization of rosemary (Rosmarinus officinalis L.) biotypes, Acta Hortic., 629, pp. 471-482.

15. Djeddi S., Bouchenah N., Settar I., Skaltsa H. (2007), Composition and antimicrobial activity of the essential oil of Rosmarinus officinalis from Algeria, Chem Nat Compd, 43(4), pp. 487-490.

16. Duke J.A. (1992), Handbook of Phytochemical Constituents of GRAS Herbs and Other Economic Plants; CRC Press: Boca Raton, FL, USA.

17. El Hattabi L., Talbaoui A. Amzazi S., Bakri Y., Harhar H., Costa J., Desjobert J.M., Tabyaoui M. (2016), Chemical composition and antibacterial activity of three essential oils from south of Morocco (Thymus satureoides, Thymus vulgaris and Chamaelum nobilis), J Materials Environ Sci, 7(9), pp. 3110-3117.

18. Fu Y., Zu Y., Chen L., Shi X.,Wang Z., Sun S., Efferth T. (2007), Antimicrobial activity of clove and rosemary essential oils alone and in combination, Phytother Res, 21(10), pp. 989-94.

19. Georgiev E., Stoyanova A. (2006), A Guide for the Specialist in the Aromatic Industry Cultivation, Plovdiv, University of Food Technologies Publ. House, 2006.

20. Gillett M. (1998), Growing and using thyme. storey publishing; North Adams, MA, USA.

21. Habtemariam S. (2016), The Therapeutic potential of rosemary (Rosmarinus officinalis) diterpenes for Alzheimer's disease. Evidence-Based complementary and alternative medicine. Article ID 2680409, pp. 14.

22. Harley R.M., Atkins S., Budantsey A.L., Cantino P.D., Conn B.J., Grayer R., Harley M.M., Kok R., Krestovskaja T., Morales R., Paton A.J., Ryding O., Upson T. Labiatae. (2004), pp. 167-275 in Kubitzki K (ed.) The Families and Genera of Vascular Plants. In Kadereit JW (ed.) Volume VII Flowering Plants Dicotyledons. Lamiales (except Acanthaceae including Avicenniaceae). (Springer: Berlin).

23. Horváth P., Koščová J. (2017), In vitro antibacterial activity of mentha essential oils against Staphylococcus aureus, Folia Vet, 61(3), pp. 71-77.

24. Hussain A.I., Anwar F., Shahid Chatha S.A., Jabbar A., Mahboob S., Nigam. (2010), Rosmarinus officinalis, P.S. essential oil: Antiproliferative, antioxidant and antibacterial activities, Braz. J. Microbiol., 41, pp. 1070-1078.

25. Kanatt S.R., Chander R., Sharma A. (2007), Antioxidant potential of mint (Mentha spicata L.) in radiation-processed lamb meat, Food Chem, 100, pp. 451-458. 
26. Karabegovic I.T., Vukosavljevic P.V., Novakovic M.M., Gorjanovic S.Ž., Džamic A.M., Lazic M.L. (2012). Influence of the storage on bioactive compounds and sensory attributes of herbal liqueur, Dig J Nanomater Biostruct, 7, pp. 1587-1598.

27. Kivilompolo M., Hyotylainen T. (2007), Comprehensive two-dimensional liquid chromatography in analysis of Lamiaceae herbs: Characterisation and quantification of antioxidant phenolic acids, J Chromatogr, 1145, pp. 155-164.

28. Marotti M., Piccaglia R., Giovannelli E. (1996), Differences in essential oil composition of basil (Ocimum basilicum L.) Italian cultivar related to morphological characteristics, J. Agric. Food Chem., 44, pp. 3926-3929.

29. Martinez-Francés V., Rios S. (2005), Lesser known herbal spirits of the Valencia and Alicante provinces (east-southern Spain). Upland \& Industrial Crops (Rural Development Administration), pp. 417-426.

30. Moghaddam A.M.D., Shayegh J., Mikaili P., Sharaf J.D. (2011), Antimicrobial activity of essential oil extract of Ocimum basilicum L. leaves on a variety of pathogenic bacteria, J Med Plant Res, 5(15), pp. 453-3456.

31. Nikšić H., Durić K., Omeragić E., Nikšić H., Muratović S., Bečić F. (2018), Chemical characterization, antimicrobial and antioxidant properties of Mentha spicata L. (Lamiaceae) essential oil, Bulletin of the Chemists and Technologists of Bosnia and Herzegovina, pp. 43-48.

32. Okmen A.S., Okmen G., Arslan A., Vurkun M. (2017), Antibacterial activities of Mentha piperita L. extracts against bacteria isolated from soccer player's shoes and its antioxidant activities, Indian J Pharm Educ, 51, pp. 163-169.

33. Politeo O., Jukic M., Milos M. (2007), Chemical composition and antioxidant capacity of free volatile aglycones from basil (Ocimum basilicum L.) compared with its essential oil, Food Chem, 101, pp. 379-385.

34. The State Pharmacopoeia of the USSR. (1990), 11th ed. Medizina. Moscow. Russia.

35. Sarer E., Yağmur Toprak S., Otlu B., Durmaz R. (2011), Composition and antimicrobial activity of the essential oil from Mentha spicata L. subsp. Spicata, J Essent Oil Res, 23(1), pp. 105-108.

36. Smith-Palmer A., Stewart J., Fyfe L. (1998), Antimicrobial properties of plant essential oils and essences against five important food-borne pathogens, Lett. Appl. Microbiol., 26, pp. 118-122.

37. Suppakul P., Miltz J., Sonneveld K., Bigger S.W. (2003), Antimicrobial properties of basil and its possible application in food packaging, J. Agric. Food Chem, 51, pp. $3197-$ 3207.

38. Tomaino A., Cimino F., Zimbalatti V., Venuti V., Sulfaro V., De Pasquale A. (2005), Influence of heating on antioxidant activity and the chemical composition of some spice essential oils, Food Chem, 89, pp. 549-554.

39. Veldhuizen E.J.A., Tjeerdsma-van Bokhoven J.L.M., Zweijtzer C., Burt S.A., Haagsman H.P. (2006), Structural requirements for the antimicrobial activity of carvacrol, J. Agric. Food Chem, 54, pp. 1874-1879.

40. Zhang Y., Adelakun T.A., Qu L. (2014), New terpenoid glycosides obtained from Rosmarinus officinalis L. aerial parts, Fitoterapia, 99, pp. 78-80. 